NISTIR 8128

\title{
Feasibility Studies for Technologies to Effectively Scrub Soot from Small- Scale Fire Experiments
}

\author{
Anthony Hamins \\ Thomas Cleary \\ Matthew Bundy
}

This publication is available free of charge from: http://dx.doi.org/10.6028/NIST.IR.8128

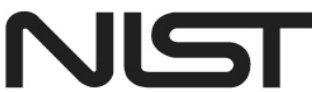

National Institute of Standards and Technology U.S. Department of Commerce 
NISTIR 8128

\section{Feasibility Studies for Technologies to Effectively Scrub Soot from Small- Scale Fire Experiments}

Anthony Hamins Thomas Cleary Matthew Bundy

Fire Research Division Engineering Laboratory

This publication is available free of charge from: http://dx.doi.org/10.6028/NIST.IR.8128

May 2016

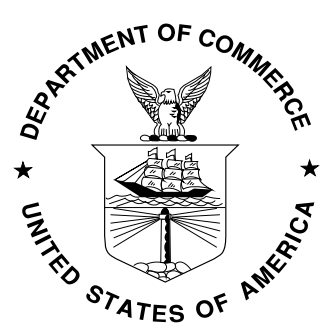

U.S. Department of Commerce Penny Pritzker, Secretary

National Institute of Standards and Technology Willie May, Under Secretary of Commerce for Standards and Technology and Director 
Certain commercial entities, equipment, or materials may be identified in this document in order to describe an experimental procedure or concept adequately. Such identification is not intended to imply recommendation or endorsement by the National Institute of Standards and Technology, nor is it intended to imply that the entities, materials, or equipment are necessarily the best available for the purpose. 


\begin{abstract}
Elimination of particulate from fire exhaust streams is a common issue for fire labs. Two series of fire experiments were conducted in the National Fire Research Laboratory (NFRL) to test technologies for possible use in the filtration of soot from the Building 224 fire research exhaust. The first experimental series used two large surface area pleated cartridge filters to capture particulate in the gas phase. The second series of experiments employed a wet scrubbing system. The experiments showed that neither technology provides adequate performance. The results showed that the first system rapidly clogged and the pressure drop across the filters did not efficiently "recover" to its pre-test value when pulsed. The particulate removal efficiency of the wet scrubbing soot filtration system was inadequate.
\end{abstract}




\section{Introduction}

During summer 2015, a survey was conducted of experimentalists in the National Institute of Standards and Technology (NIST) Fire Research Division on the amount of particulate generation from exhaust hoods in Building 224. The survey results are shown in Table 1. Based on recent history and projected experimental plans, it was determined that about $11 \mathrm{~kg}$ of combustion particulate, primarily soot, was expected to be generated on-average per year. The amount of soot generated varies depending on the amount and type of materials burned. A wide range of test materials were identified as seen in the table. While the historic data in the table is based on lab notes and is probably fairly accurate, the uncertainty of the projected values was difficult to estimate. ${ }^{i}$ The estimated soot emission values listed in Table 1 were provided to the State of Maryland Office of Environmental Compliance, ${ }^{\mathrm{ii}}$ which subsequently provided an exemption to the requirement of no visible emission of particulate from fire research activities in Building 224. Although an exemption allows continuation of current fire research experiments, it does not guarantee that future needs with possibly larger soot emission will be allowed. For this reason, the experiments described below were conducted to test the performance of various technologies to filter soot from a fire product stream.

Recently, the NIST Building 224 fire research exhaust was refurbished and fitted with a filter assembly that allows three layers of filtration. Each layer is composed of 12 planar filters - each with a $0.4 \mathrm{~m}^{2}\left(4 \mathrm{ft}^{2}\right)$ area, for a total of $4 \mathrm{~m}^{2}\left(48 \mathrm{ft}^{2}\right)$ total system area. Experience with this system showed that the first layer of 12 planar filters clogged (about $1 \mathrm{kPa}$ or 4 in of water column pressure drop) within 15 min of burning of a $5 \mathrm{~cm}$ diameter toluene pool fire with $100 \mathrm{ml}$ of toluene (87 g). With a soot yield of about $20 \%$ [1], the toluene fires were estimated to have clogged the filtration system with about $16 \mathrm{~g}$ of soot - a soot mass loading on the filters of roughly $4 \mathrm{~g} / \mathrm{m}^{2}\left(0.4 \mathrm{~g} / \mathrm{ft}^{2}\right)$. This soot filtration system is not cost effective and does not provide adequate mass collection for the needs of the fire research enterprise in Building 224.

It should be noted that soot filtration is an issue facing many fire laboratories, including those in Maryland and Montgomery County. A number of fire labs do not scrub particulate from the exhaust of small (e.g., cone calorimeter at the Consumer Product Safety Commission Rockville facility, Montgomery County’s Fire and Rescue Department, and the Fire Protection Engineering Department at the University of Maryland at College Park) and even moderate-scale (order of $500 \mathrm{~kW}$ ) fire experiments (University of Maryland at College Park and the Fire Protection Engineering Department at Worcester Polytechnic University).[2, 3, 4, 5]. Thus, a cost-effective treatment process would be of general interest to the fire testing and research communities.

Soot has unique properties - it is "fluffy" with a very low bulk density. It is an effective attenuator of visible light. When illuminated, it absorbs and scatters light. Even small amounts of soot can be visualized. The objective of these experiments was to test the performance of technologies that filter soot-laden flow such that no particle emission is visible, or at least remove a large fraction of the flow particulate. The fire source is a $20 \mathrm{~cm}$ diameter toluene pool fire. Toluene has a high soot yield and this fire is considered representative of a source that produces a challenging, yet plausible, amount of soot loading for the exhaust system in

i. The projected values for 2016 appear to have been significantly over-estimated.

ii. through the NIST Safety Office. 
Table 1. Results from 2015 staff survey on historic and anticipated soot emission in Building 224.

\begin{tabular}{|c|c|c|c|c|c|c|c|}
\hline Year & $\begin{array}{l}\text { Number } \\
\text { of Tests }\end{array}$ & Apparatus & $\begin{array}{c}\text { Estimated Fuel } \\
\text { Mass Loss/Test (g) }\end{array}$ & Material & $\begin{array}{l}\text { Soot Yield } \\
\text { [1] }\end{array}$ & $\begin{array}{l}\text { Soot Emitted during } \\
\text { Typical Test (g) }\end{array}$ & $\begin{array}{c}\text { Estimated } \\
\text { Soot }(\mathrm{g}) / \text { year }\end{array}$ \\
\hline 2012 & 75 & cone (vitiated) & 200 & Foam, wood, cable & 0.05 & 10.0 & 750 \\
\hline 2012 & 30 & Cone & 280 & Polymer nanocomposites & 0.02 & 5.6 & 168 \\
\hline 2012 & 30 & Cone & 100 & $\begin{array}{c}\text { Polyurethane foam (PUF), } \\
\text { polymethylmethacrylate (PMMA), } \\
\text { Wood }\end{array}$ & 0.03 & 3.0 & 90 \\
\hline 2012 & 140 & Cone & 250 & Cables & 0.02 & 5.0 & 700 \\
\hline 2012 & 40 & Cone & 100 & Wood, Particle Board, Fabric & 0.02 & 2.0 & 80 \\
\hline 2012 & 50 & Cone & 30 & Barrier Fabrics & 0.02 & 0.6 & 30 \\
\hline 2012 & 30 & Cone & 30 & Foams & 0.05 & 1.5 & 45 \\
\hline 2012 & 180 & Cone & 100 & $\begin{array}{l}\text { Fire Retarded (FR) foam, control } \\
\text { foam }\end{array}$ & 0.1 & 10.0 & 1800 \\
\hline 2012 & 15 & Cone & 20 & Fire Retarded Foams & 0.1 & 2.0 & 30 \\
\hline 2013 & 190 & Cone & 20 & Foams & 0.02 & 0.4 & 36 \\
\hline 2013 & 115 & Cone & 20 & Cables & 0.02 & 0.4 & 46 \\
\hline 2013 & 50 & Cone & 20 & Fabric & 0.02 & 0.4 & 20 \\
\hline 2013 & 10 & Cone & 300 & Polystyrene & 0.02 & 6.0 & 60 \\
\hline 2013 & 74 & Cone & 300 & Particleboard & 0.02 & 6.0 & 444 \\
\hline 2013 & 5 & Cone & 300 & PMMA & 0.02 & 6.0 & 30 \\
\hline 2013 & 3 & Cone & 300 & $\begin{array}{l}\text { PMMA, Polyethylene (PE), } \\
\text { Polystyrene (PS) }\end{array}$ & 0.05 & 15.0 & 45 \\
\hline 2013 & 6 & Cone & 300 & Polyol & 0.02 & 6.0 & 36 \\
\hline 2013 & 65 & Cone & 100 & Carpet & 0.02 & 2.0 & 130 \\
\hline 2013 & 15 & Radiant Panel & 500 & Polyvinylchloride (PVC) & 0.02 & 10.0 & 150 \\
\hline 2013 & 200 & Cone & 100 & PUF & 0.10 & 10.0 & 2000 \\
\hline 2013 & 100 & Cone & 250 & PMMA & 0.02 & 5.0 & 500 \\
\hline 2014 & 100 & LIFT & 1000 & Nylon carpet & 0.02 & 20.0 & 2000 \\
\hline 2014 & 200 & TPP & 10 & Polyphenylene Ether (PPE) & 0.02 & 0.2 & 40 \\
\hline 2014 & 100 & Cone & 150 & PMMA & 0.01 & 1.5 & 150 \\
\hline
\end{tabular}




\begin{tabular}{|c|c|c|c|c|c|c|c|}
\hline Year & $\begin{array}{l}\text { Number } \\
\text { of Tests }\end{array}$ & Apparatus & $\begin{array}{c}\text { Estimated Fuel } \\
\text { Mass Loss/Test } \\
\text { (g) }\end{array}$ & Material & $\begin{array}{c}\text { Soot Yield } \\
\text { [1] }\end{array}$ & $\begin{array}{c}\text { Soot Emitted } \\
\text { during Typical } \\
\text { Test (g) }\end{array}$ & $\begin{array}{c}\text { Estimated } \\
\text { Soot }(g) / \text { year }\end{array}$ \\
\hline 2015 & 100 & Radiant Panel & 2500 & PVC & 0.04 & 100.0 & 10000 \\
\hline 2015 & 100 & Cone & 20 & PUF & 0.10 & 2.0 & 200 \\
\hline 2016 & 800 & Cone & 200 & PUF (80\%)/wood (20\%) & 0.05 & 10.0 & 8000 \\
\hline 2016 & 30 & Radiant Panel & 100 & Wood (red oak) & 0.02 & 2.0 & 60 \\
\hline 2016 & 30 & Radiant Panel & 50 & Polystyrene (PS) & 0.20 & 10.0 & 300 \\
\hline 2016 & 30 & Radiant Panel & 50 & PVC & 0.10 & 5.0 & 150 \\
\hline 2016 & 20 & Flooring RP & 100 & Polypropylene & 0.06 & 6.0 & 120 \\
\hline 2016 & 20 & Flooring RP & 100 & Nylon & 0.08 & 8.0 & 160 \\
\hline 2016 & 20 & Flooring RP & 200 & Wood (red oak) & 0.02 & 4.0 & 80 \\
\hline 2016 & 20 & LIFT & 200 & Wood (red oak) & 0.02 & 4.0 & 80 \\
\hline 2016 & 20 & LIFT & 100 & PS & 0.20 & 20.0 & 400 \\
\hline 2016 & 20 & LIFT & 100 & PVC & 0.10 & 10.0 & 200 \\
\hline 2017 & 1000 & Cone & 250 & PS (unexpanded) & 0.10 & 25.0 & 25000 \\
\hline 2017 & 100 & Detection Lab & 50 & Cooking stuff (food, oil) & 0.02 & 1.0 & 100 \\
\hline 2017 & 800 & $\mathrm{FE} / \mathrm{DE}$ & 12.5 & Propene & 0.06 & 0.8 & 600 \\
\hline 2017 & 500 & textile testing & 200 & Fabrics & 0.05 & 10.0 & 5000 \\
\hline 2017 & 120 & Radiant Panel & 100 & Wood (red oak) & 0.02 & 2.0 & 240 \\
\hline 2017 & 120 & Radiant Panel & 50 & Polystyrene & 0.20 & 10.0 & 1200 \\
\hline 2017 & 120 & Radiant Panel & 50 & PVC & 0.10 & 5.0 & 600 \\
\hline 2017 & 80 & Flooring RP & 100 & Polypropylene & 0.06 & 6.0 & 480 \\
\hline 2017 & 80 & Flooring RP & 100 & Nylon & 0.08 & 8.0 & 640 \\
\hline 2017 & 80 & Flooring RP & 200 & Wood (red oak) & 0.02 & 4.0 & 320 \\
\hline 2017 & 80 & LIFT & 200 & Wood (red oak) & 0.02 & 4.0 & 320 \\
\hline 2017 & 80 & LIFT & 100 & Polystyrene & 0.20 & 20.0 & 1600 \\
\hline 2017 & 80 & LIFT & 100 & PVC & 0.10 & 10.0 & 800 \\
\hline $\begin{array}{l}\text { Avera } \\
\text { ge }\end{array}$ & $\begin{array}{c}1028 \\
\text { tests/yr }\end{array}$ & - & $200 \mathrm{~g} /$ test & - & - & $8.5 \mathrm{~g} /$ test & $11 \mathrm{~kg} /$ year \\
\hline
\end{tabular}


Building 224. The ultimate interest is to provide a cost effective way to reduce the amount of particulate in the exhaust of experiments conducted by NIST's fire research program in Building 224 on the NIST campus. To this end, two series of experiments were conducted in the NIST National Fire Research Laboratory (NFRL) to test technologies for possible use in the filtration of soot.

The first series of experiments in the NFRL used two large surface area pleated cartridge filters to capture the particulate in the gas phase. The second series of experiments employed a wet scrubbing system. These technologies were selected for testing based on recommendations in a report commissioned to evaluate alternative soot filtration technologies for possible implementation at the new Consumer Product Safety Commission (CPSC) laboratory in Rockville, Maryland by a fire protection engineer in consultation with industry particle filtration experts [6]. Obviously, there are many possible ways to scrub soot from combustion generated flows, including a baghouse, such as that implemented at the NIST NFRL. The technologies tested in this study were selected in terms of costs (initial cost and maintenance) and practicality (e.g., available space).

\section{Cartridge Filtration Experiments}

Dust collection cartridge filters are used in the biomass, gas turbine, and industrial boiler industries among others. The promise was that these are highly effective and when pretreated, able to accommodate high particulate loadings, and then through air pulsation, drop the collected particulate into a hopper installed below the filter. It should be noted that the Consumer Product Safety Commission (CPSC) was considering such a system in their new laboratory based on technical recommendations from experts in industry and the fire research community. A series of experiments were designed to test the performance of such a system.

The first series of experiments involved nine tests conducted using $20 \mathrm{~cm}$ diameter toluene pool fire and two tests using polystyrene/heptane pool fires, all about $20 \mathrm{~kW}$ to $30 \mathrm{~kW}$ in measured heat release rate. A photo of the experimental set-up is shown in Figure 1. A round metal burner with an inner diameter of $21.5 \mathrm{~cm}$ (8.5 in) and $11.5 \mathrm{~cm}$ (4.5 in) deep was used for all experiments except the first two, when a $30 \mathrm{~cm}$ square metal burner was used. A total of about $1.4 \mathrm{~kg}$ of toluene was burnt with an estimated $20 \%$ soot yield soot [Error! Bookmark not defined.] generated by the 9 toluene fires. Two cartridge filters were used to capture particulate in the exhaust stream. The filters, roughly cylindrical in shape, $1 \mathrm{~m}$ (39 in) long and $0.36 \mathrm{~m}$ (14 in) diameter, each had a highly pleated surface area of $39.5 \mathrm{~m}^{2}\left(425 \mathrm{ft}^{2}\right)$, or a surface area of $79.0 \mathrm{~m}^{2}$ $\left(850 \mathrm{ft}^{2}\right)$ for the two filters. Not considering the pleats, the outer surface area of each of the cylinders was about $1.10 \mathrm{~m}^{2}\left(11.8 \mathrm{ft}^{2}\right)$, yielding a ratio of pleated surface area to outer surface area of about 36. As recommended by the filter manufacturer, the filters were pre-treated with diatomaceous earth before each of the experiments. A larger amount was used initially, which was decreased for subsequent tests until no pre-coat was used for Tests 7 - 9, when the effect of not pretreating the filters was investigated. Not all the pre-coat stuck to the filters; some amount was observed on the bottom of the filter assembly. The filter assembly housed the two filters (flow in parallel through the filters) as seen on the left of the image. 
The fuel used in all tests was toluene, except Tests 1 and 2 . The fuel used in Test 1 was $2 \mathrm{~kg}$ of Polystyrene (PS) plus $500 \mathrm{~mL}$ of heptane (340 g). The fuel used in Test 2 was $2 \mathrm{~kg}$ of PS plus $250 \mathrm{~mL}$ of heptane (170 g). The polystyrene (PS) plus heptane fires burned for approximately 4 min to 6 min until they were extinguished. Not all of the fuel was consumed during the first two tests. There appeared to be some amount of liquid, presumably heptane, on the bottom of the burner after the first experiment. Since the mass loss of heptane and PS are not similar, the mass loss and estimated soot yield are not accurate for polystyrene, since the fractions of heptane and PS burned are unknown. Subsequent experiments exclusively used toluene.

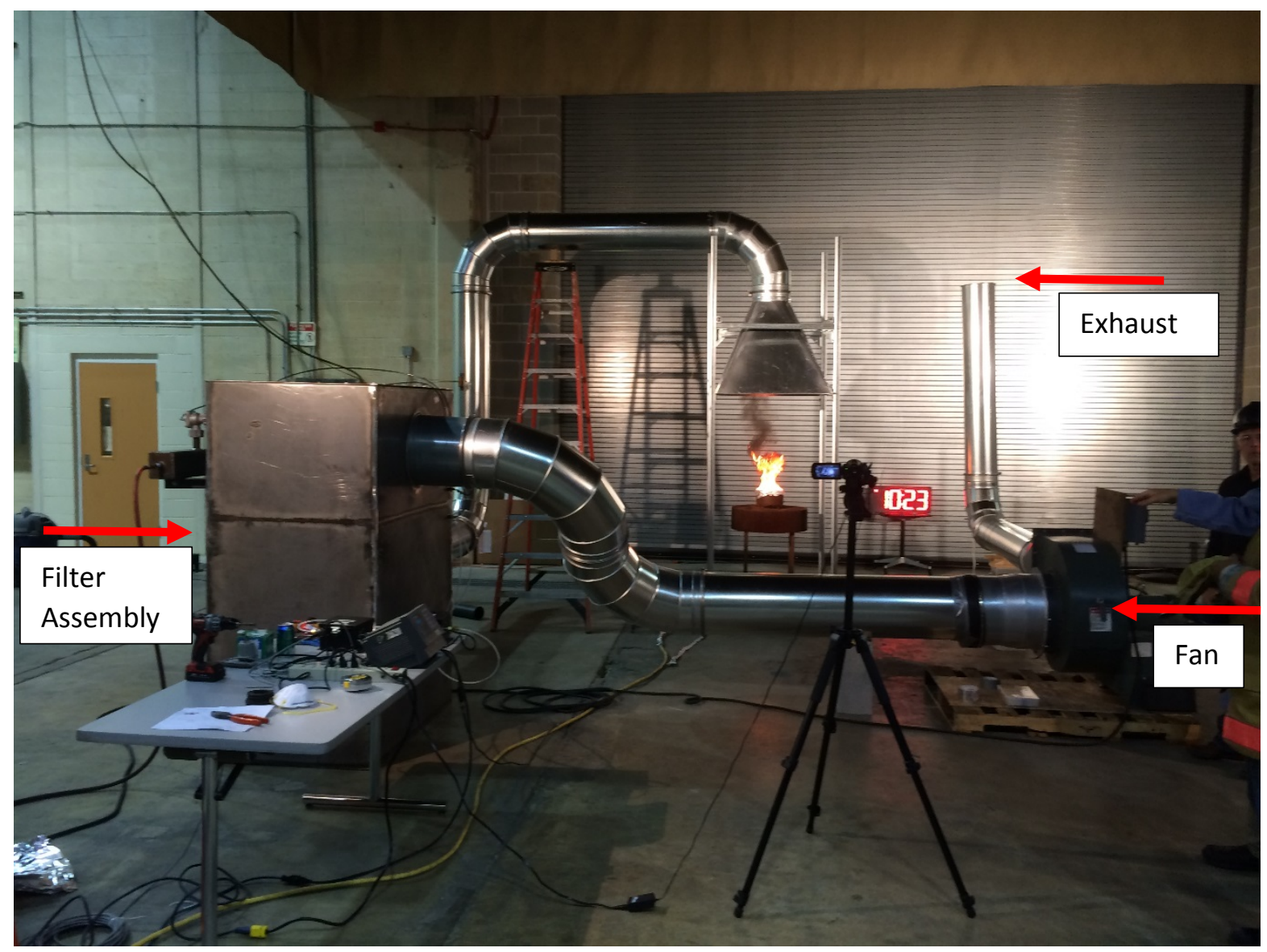

Figure 1. Toluene pool fire burning during the first soot filtering experimental series conducted in the NFRL on July 10, 2015. Smoke emitted by the toluene fire is evident, while no smoke plume was observed at the illuminated vertical exhaust duct on the right side of the image.

As the test proceeded, soot was trapped by the filters and the pressure drop across the filters increased. After each test, the filters were rapidly pulsed as recommended by the manufacturer, to open the pleats and remove particulate material from the filter, permitting it to fall to the bottom of the assembly. This was repeated several times as the pressure drop was observed. After pulsing, the cartridge filter appeared covered in soot (see Figure 2) and some amount of light-color diatomaceous earth was observed to cover the bottom of the assembly and its wall surfaces. 
Table 2 shows the fuel mass loss and the peak heat release rate (HRR) during the experiments. The HRR varied from about $30 \mathrm{~kW}$ to $50 \mathrm{~kW}$. The toluene pool fires (Tests 3 - 9) were allowed to burn approximately $3 \mathrm{~min}$ to $6 \mathrm{~min}$ when the pressure drop across the cartridge filters increased to a point that the fan could not maintain flow. The mass loss for each test is listed in Table 2. The estimated soot in the flow (based on a $20 \%$ soot yield) varied from $20 \mathrm{~g}$ to $70 \mathrm{~g}$. As the tests were conducted, the filters clogged much more rapidly than expected as observed by the increasing pressure drop across the filters. Table 2 shows that during the toluene fuel tests (Tests 3 -9), the pressure drop increased from about $300 \mathrm{~Pa}$ to $700 \mathrm{~Pa}$ (1 in to 3 in of water column) in about $3 \mathrm{~min}$ to $6 \mathrm{~min}$ of burning, capturing an estimated $25 \mathrm{~g}$ to $67 \mathrm{~g}$ of soot.

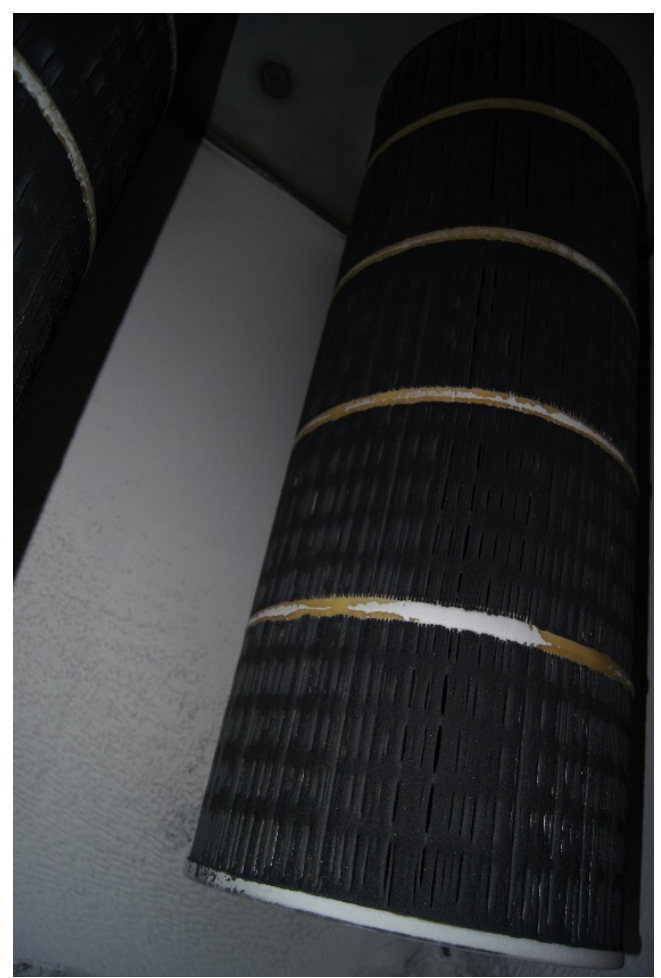

Figure 2. Soot covered the cartridge filters, looking upwards within the filter assembly box (see Figure 1). Some amount of light-color diatomaceous earth can be seen on the assembly wall surfaces behind and to the left of the filter.

Although a relatively thin layer of particulate (pre-coat material and carbonaceous soot) was visible on the pleated surfaces, the outer portions of the filters were thick with particulate (see Figure 2). If the full pleated surface of the filters was effective, then there would be about $79 \mathrm{~m}^{2}$ $\left(850 \mathrm{ft}^{2}\right)$ of effective filter surface area available and the filtration effectiveness as characterized by the soot mass loading would vary from about $0.3 \mathrm{~g} / \mathrm{m}^{2}$ to $0.9 \mathrm{~g} / \mathrm{m}^{2}\left(0.03 \mathrm{~g} / \mathrm{ft}^{2}\right.$ to $\left.0.08 \mathrm{~g} / \mathrm{ft}^{2}\right)$ for the experiments. This result is 10 to 30 times smaller than expected when compared to the results found by CPSC during analogous experiments using the same toluene burner, with a 
measured value of $10 \mathrm{~g} / \mathrm{m}^{2}\left(0.9 \mathrm{~g} / \mathrm{ft}^{2}\right)$. ${ }^{\text {iii }}$ [4] As expected, the CPSC result is the same order of magnitude as that found for the Building 224 planar filtration system as described above - a value of about $4 \mathrm{~g} / \mathrm{m}^{2}\left(0.4 \mathrm{~g} / \mathrm{ft}^{2}\right)$. This suggests that the effective surface area of the cartridge filter was closer to the $3.6 \mathrm{~m}^{2}\left(24 \mathrm{ft}^{2}\right)$ outer surface area of the cylindrical cartridges with a corresponding range of soot filtration effectiveness varying from $0.10 \mathrm{~g} / \mathrm{m}^{2}\left(1.1 \mathrm{~g} / \mathrm{ft}^{2}\right)$ to $0.26 \mathrm{~g} / \mathrm{m}^{2}\left(2.8 \mathrm{~g} / \mathrm{ft}^{2}\right)$ as shown in Table 2 . Based on these results, the cartridge filter technology was not seen as an attractive option for soot filtration.

Table 2. Results from experiments using two large-area pleated filters.

\begin{tabular}{|c|l|c|c|c|c|c|c|c|c|}
\hline Test & \multicolumn{1}{|c|}{ Fuel } & $\begin{array}{c}\text { Fuel } \\
\text { Mass } \\
\text { Loss } \\
(\mathrm{g})\end{array}$ & $\begin{array}{c}\text { Peak } \\
\text { HRR } \\
(\mathrm{kW})\end{array}$ & $\begin{array}{c}\text { Estimated } \\
\text { Soot }(\mathrm{g})\end{array}$ & $\begin{array}{c}\text { Precoat } \\
(\mathrm{kg})\end{array}$ & $\begin{array}{c}\text { Initial } \\
\mathrm{P}(\mathrm{Pa})\end{array}$ & $\begin{array}{c}\Delta \mathrm{P} \text { during } \\
\text { burn (Pa) }\end{array}$ & $\begin{array}{c}\text { Soot Mass } \\
\text { over 850 } \mathrm{ft}^{2} \\
\left(\mathrm{~g} / \mathrm{ft}^{2}\right)\end{array}$ & $\begin{array}{c}\text { Soot Mass } \\
{\text { over } 24 \mathrm{ft}^{2}}^{\left(\mathrm{g} / \mathrm{ft}^{2}\right)}\end{array}$ \\
\hline $\mathbf{1}$ & $\begin{array}{l}\text { Polystyrene } \\
\text { /Heptane }\end{array}$ & 363 & 50 & 33 & 5 & 340 & 135 & 0.04 & 1.4 \\
\hline $\mathbf{2}$ & $\begin{array}{l}\text { Polystyrene } \\
\text { /Heptane }\end{array}$ & 235 & 23 & 22 & 2 & 570 & 365 & 0.03 & 0.9 \\
\hline $\mathbf{3}$ & Toluene & 129 & 23 & 26 & 2 & 650 & 374 & 0.03 & 1.1 \\
\hline $\mathbf{4}$ & Toluene & 170 & 25 & 34 & 2 & 550 & 452 & 0.04 & 1.4 \\
\hline $\mathbf{5}$ & Toluene & 209 & 29 & 42 & 1 & 500 & 503 & 0.05 & 1.7 \\
\hline $\mathbf{6}$ & Toluene & 333 & 33 & 67 & 0.5 & 415 & 578 & 0.08 & 2.8 \\
\hline $\mathbf{7}$ & Toluene & 290 & 30 & 58 & 0 & 367 & 666 & 0.07 & 2.4 \\
\hline $\mathbf{8}$ & Toluene & 209 & 32 & 42 & 0 & 387 & 627 & 0.05 & 1.7 \\
\hline $\mathbf{9}$ & Toluene & 126 & 29 & 25 & 0 & 478 & 465 & 0.03 & 1.1 \\
\hline
\end{tabular}

\section{Wet Scrubbing Filtration Experiments}

Wet scrubbers remove particulates from gas flows by means of inertial or diffusional interception of particulate matter with water droplets introduced in the flow. They include spray, entrainment, and Venturi scrubber designs to induce particulate/droplet interaction. Reported collection efficiencies are typically about $80 \%$ or higher for particles with aerodynamic diameters $2.5 \mu \mathrm{m}$ or greater.

The second series of experiments employed the same $20.3 \mathrm{~cm}$ diameter round pool burning $500 \mathrm{ml}$ of toluene as used during the first series of experiments. A two-stage horizontallyoriented wet-scrubbing system was used to filter the soot. A photo of the experimental set-up is shown in Figure 3. The first stage of the scrubbing system flowed the particle laden flow through a water-flooded packed media section designed to remove particulate greater than

iii. The CPSC uses a commercial system to scrub soot. The fire exhaust flows through a filter media, which traps the particulate. As the media becomes loaded with particulate, the pressure drop across the filter increases and the system automatically indexes a new section of filter material into the flow stream. 
$40 \mu \mathrm{m}$. The structured packed bed scrubber was housed in a metal compartment (0.5 m wide, $2.1 \mathrm{~m}$ long, and $1.4 \mathrm{~m}$ tall) and employed seven spray nozzles (similar to water sprinklers in design as seen in Figure 4) that provided water droplets that coated an offset vertical metal matrix (denoted a mist eliminator by industry) shown in Figure 5. The nozzle was design to provide water droplets on the order of a millimeter in diameter with a spray pattern over a $15 \mathrm{~cm}$ round area. A self-priming circulation pump ( $500 \mathrm{~L} / \mathrm{min}$ ) provided continuous water to a shelf to which the nozzles were attached. The eliminator section in the scrubber was designed to strip-off the droplets and mist carried over from the scrubbing element, and as the droplets impinged against the mist eliminator, remove the droplets from the flow.

The second stage was a metal sieve tray scrubber housed in a metal compartment ( $0.5 \mathrm{~m}$ wide, $2.1 \mathrm{~m}$ long, and $1.6 \mathrm{~m}$ tall) containing a series of water cascades and connected in series to the first stage. In one key experiment (Test 10), the water flow was turned off to investigate the importance of the water on the performance of the system. A number of instruments were used to characterize soot in the exhaust flow and thereby the effectiveness of the scrubbing system. Soot mass was determined gravimetrically and by laser light extinction. A cascade impactor was used to measure the particle size distribution in the flow.

Bouguer's Law relates the ratio of the transmitted (I) and incident ( $\left.\mathrm{I}_{\mathrm{o}}\right)$ intensities of light to the soot mass concentration $\left(\mathrm{M}_{\mathrm{s}}\right)$, the pathlength through the smoke $(\mathrm{L})$, and the mass specific soot extinction coefficient $\left(\sigma_{s}\right)$ through the following expression: $I / I_{0}=\exp \left(-\sigma_{s} M_{s} L\right)$. Figure 6 shows the laser/detector system and soot sampling probe at the exhaust duct. The laser beam and detector were mounted on steel rods, ensuring laser alignment, and separated by $25 \mathrm{~cm}$. The laser was positioned just above the exit of the duct, providing a measurement of light extinction (at $635 \mathrm{~nm}$ wavelength; visible light in the red part of the spectrum).

Once soot was collected by the scrubbers, it appeared to stay suspended in the water. A pressurized filter apparatus shown in Figure 7 was used to remove the suspended solids from the liquid. Figure 8 shows a soot "cake” on the filter media after processing. This approach was quite effective as seen in the photos with the water very clear after treatment.

The water in the scrubbers was changed out once during the experiments. The water was rather dark with suspended soot. Mixing of the soot suspension was enhanced by adding a small amount of surfactant (about $50 \mathrm{ml}$ ) to the $500 \mathrm{~L}$ of water inside the scrubbers.

The laser was allowed to warm-up before the experiment to minimize the rate of signal drift. Signal strength and background were measured before and after each experiment. Signal drift was removed by subtracting an assumed linear laser power drift. Figure 9 to Figure 11 show the laser extinction raw signal, corrected signal, and calculated soot concentration of the flow given the $25 \mathrm{~cm}$ path length across the duct, and the mass specific soot extinction coefficient $\left(8.7 \mathrm{~m}^{2} / \mathrm{g}\right)$.[7] The detector signal upward drift in Figure 9 was due to a change in the laboratory ambient temperature caused by the inflow of cold outside make-up air just prior to and during the experiment inducing a gradual increase in the laser power. Had the laser been given time to 


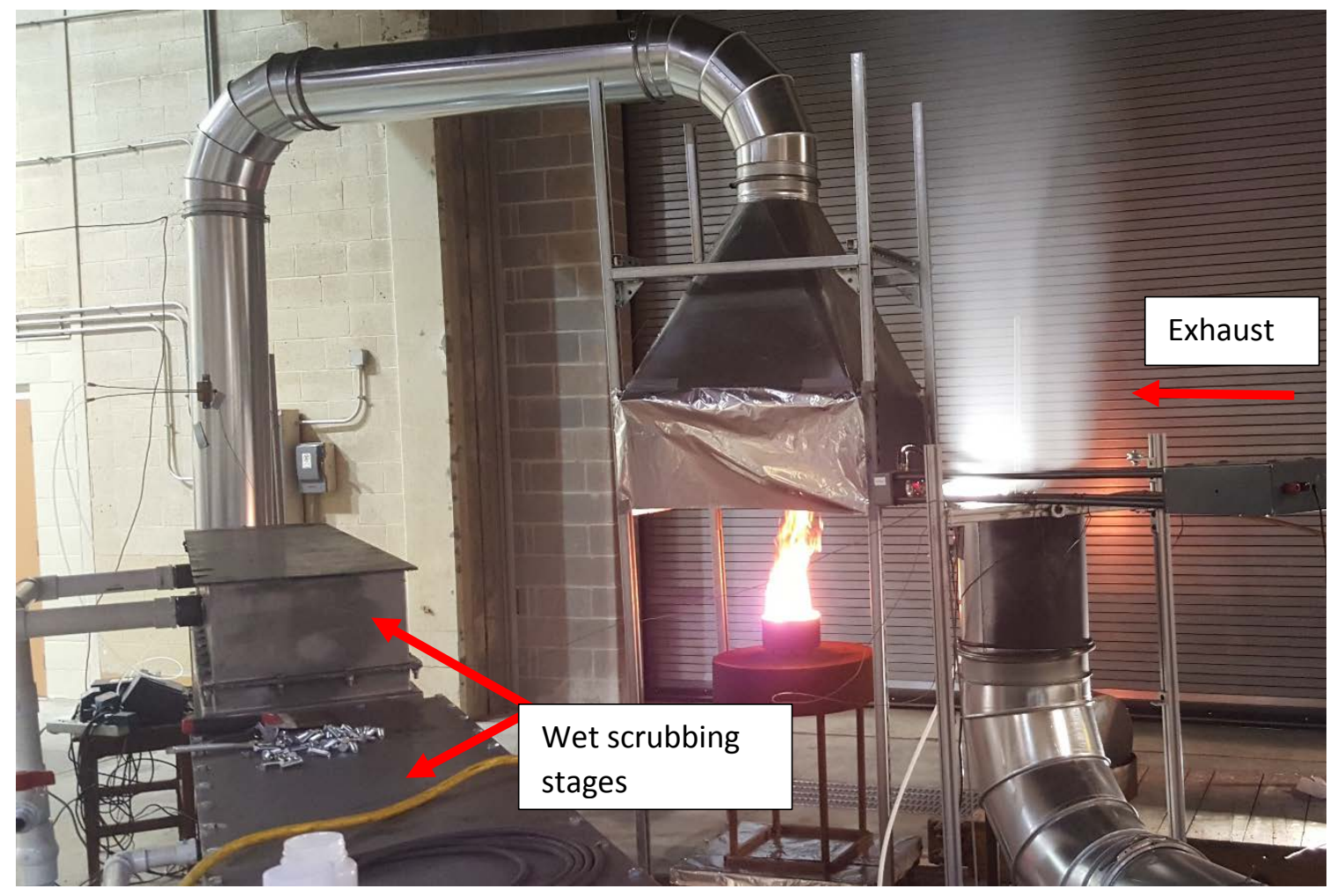

Figure 3. Toluene pool fire burning during the second soot filtering experimental series conducted in the NFRL on November 24, 2015. A visible smoke plume was observed at the illuminated vertical exhaust duct as seen on the right side of the image.

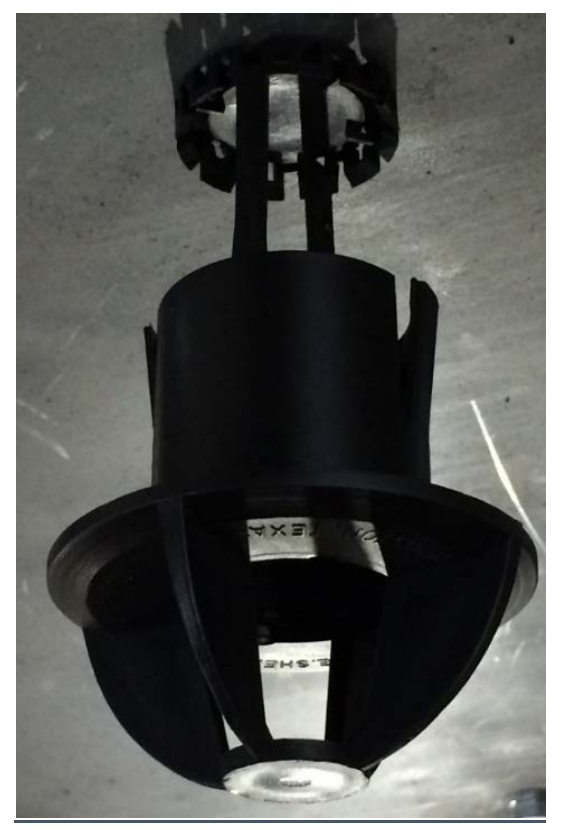

Figure 4. One of seven spray nozzles used to scrub soot in the first stage of the scrubbing assembly. 


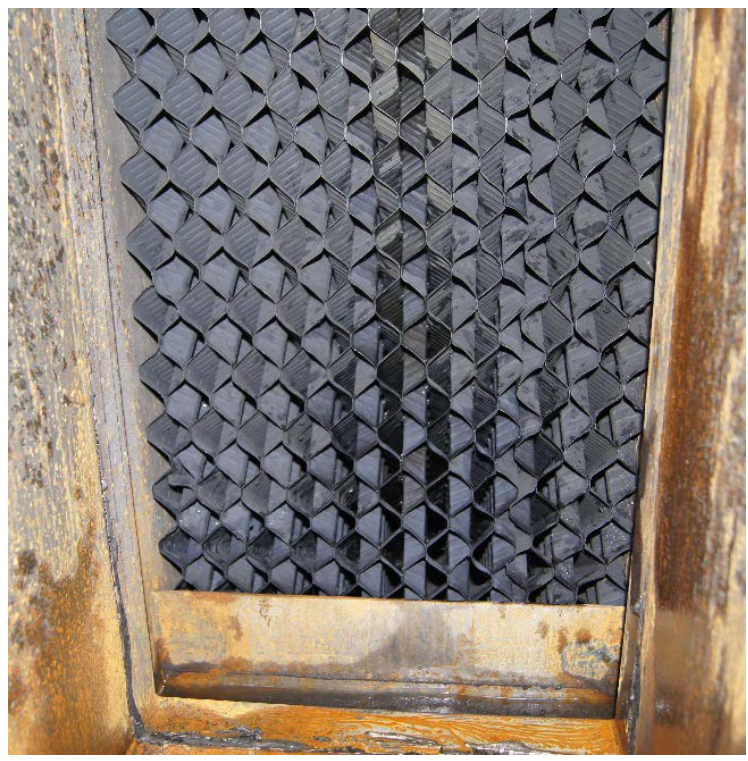

Figure 5. Vertical metal matrix assembly used in first stage of the wet scrubbing system.

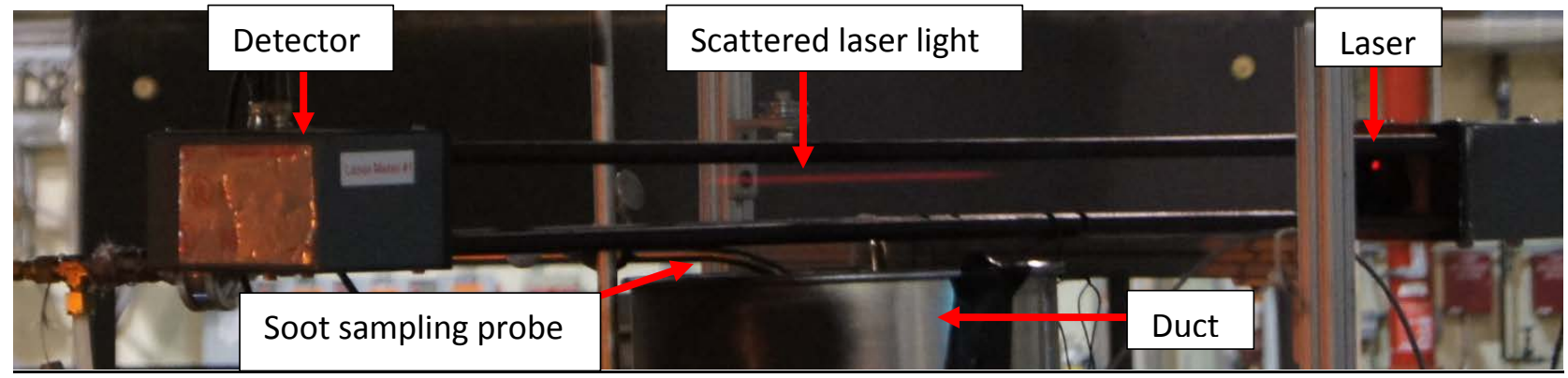

Figure 6. Exhaust duct instrumented with a red laser/detector system and soot sampling probes. Laser light scattered by soot in the flow is evident above the duct. 


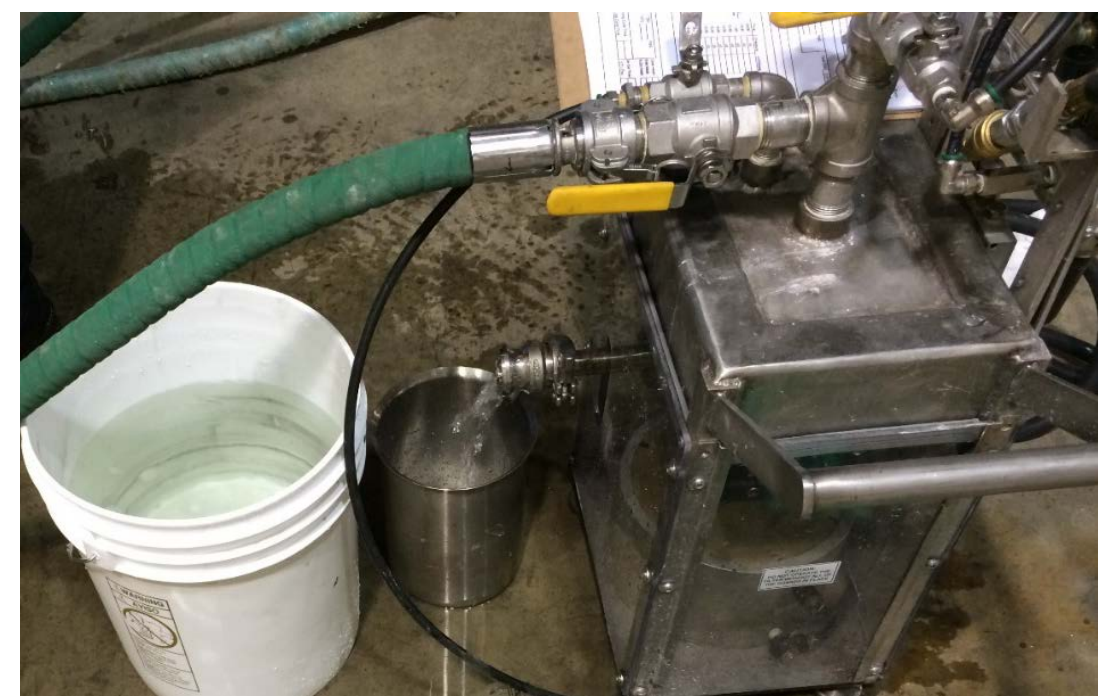

Figure 7. Pressurized filter device used to remove soot from the water. Filtered water (soot removed) is seen in the bucket and flowing from the device.

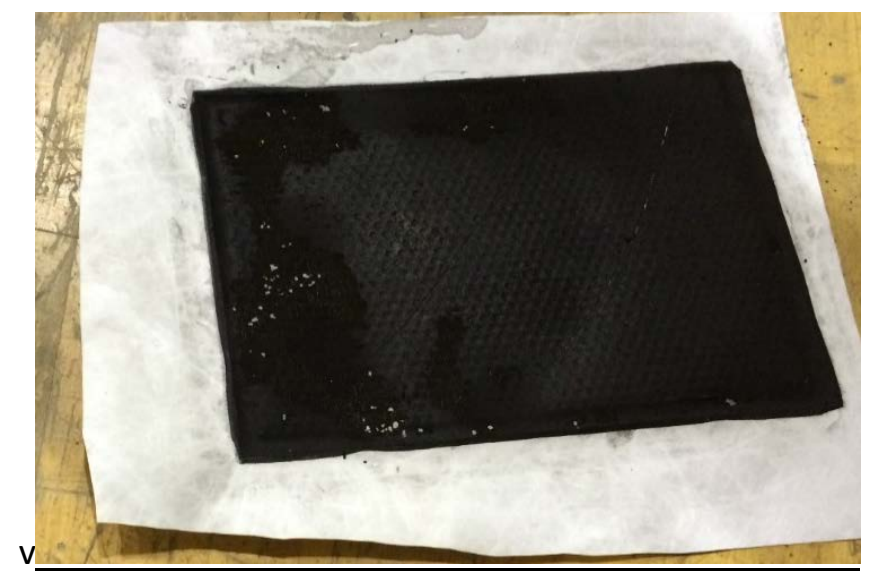

Figure 8. Soot “cake” on TYVEC filter media extracted from water using the pressurized filter apparatus shown in Figure 7. 
stabilize to the ambient room temperature, the drift would have been much less severe, e.g. Test 9 with the signal shown in Figure 10. The soot mass flow rate in the exhaust was computed by multiplying the volumetric flow by the soot concentration. Integrating over the duration of the experiment provides an estimate of the total soot mass exiting the exhaust duct, which can be compared to the estimated soot yield from the toluene pool fire. The relative expanded uncertainty is on the order of $20 \%$ for the soot mass exiting the exhaust duct. Table 3 summarizes the results from the laser experiments which showed that the percentage soot sampled in the exhaust stream ranged from about $67 \%$ to $70 \%$ of the expected soot yield, implying a system collection efficiency of about one-third. A comparison of the results from Test 10 to those of Tests 8 and 9 suggests that water in the scrubbing system had little effect on scrubber performance. Thus, much of the soot collection was apparently not due to water scrubbing, but simply soot losses on surfaces - either within the scrubber or external to it.

Table 3. Results from wet scrubbing experiments.

\begin{tabular}{|c|c|c|c|c|c|c|c|}
\hline Test & Fuel & $\begin{array}{c}\text { Water } \\
\text { Scrubbing }\end{array}$ & $\begin{array}{c}\text { Fuel } \\
\text { Volume (ml) }\end{array}$ & $\begin{array}{c}\text { Fuel } \\
\text { Mass (g) }\end{array}$ & $\begin{array}{c}\text { Estimated } \\
\text { Soot Yield (g) }\end{array}$ & $\begin{array}{c}\text { Mass (g) } \\
\text { from Laser } \\
\text { Measurement }\end{array}$ & $\begin{array}{c}\text { Percentage Soot in } \\
\text { exhaust at Sampling } \\
\text { Location }\end{array}$ \\
\hline 8 & Toluene & On & 500 & 433 & 87 & 61 & $70 \%$ \\
\hline 9 & Toluene & On & 500 & 433 & 87 & 60 & $69 \%$ \\
\hline 10 & Toluene & Off & 500 & 433 & 87 & 59 & $67 \%$ \\
\hline
\end{tabular}

A 10-stage cascade impactor was assembled with greased aluminum foil impaction substrates and a (PTFE) after filter. Impaction substrates were coated, weighed and reweighed more than $24 \mathrm{~h}$ later to establish stable coated substrate initial mass. The soot-laden flow before (Test 9) and after (Test 8) the wet scrubber was sampled iso-kinetically in two separate experiments. The soot sampling probe consisted of a $7.4 \mathrm{~mm}$ (internal diameter) copper tube aligned directly towards the incoming flow. The probe was approximately positioned in the middle of the duct, either near the duct exit or about $1 \mathrm{~m}$ before the first scrubbing stage. Sampling times were $200 \mathrm{~s}$ and 100 s during Test 8 and Test 9, respectively. The sample flowed through an assembly fitted with dried and weighed polytetrafluoroethylene (PTFE) filters to collect soot. The sample flow 


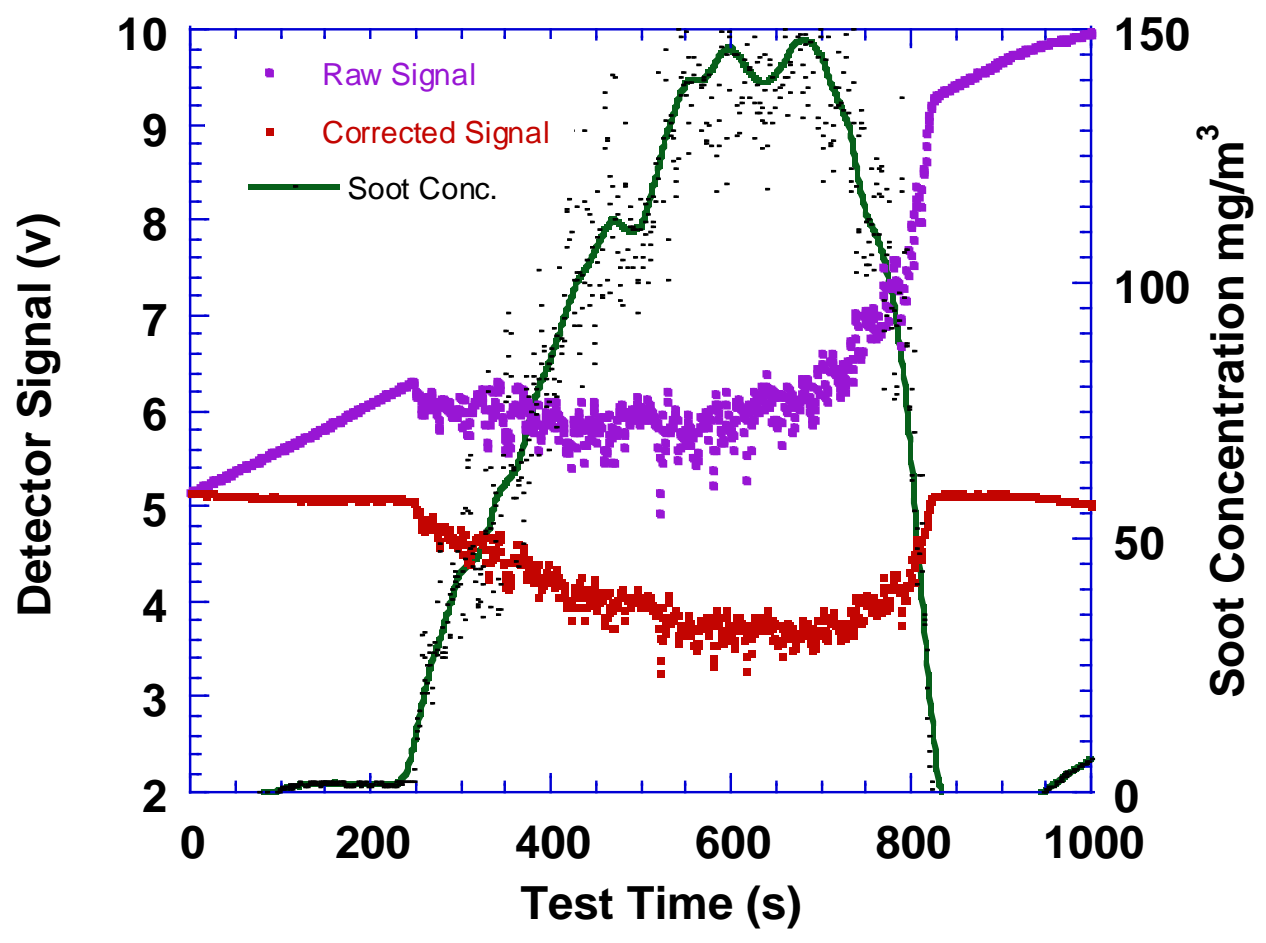

Figure 9. Soot concentration determined from the baseline corrected laser signal measured in the fire exhaust duct exit after the wet scrubber during Test 8.

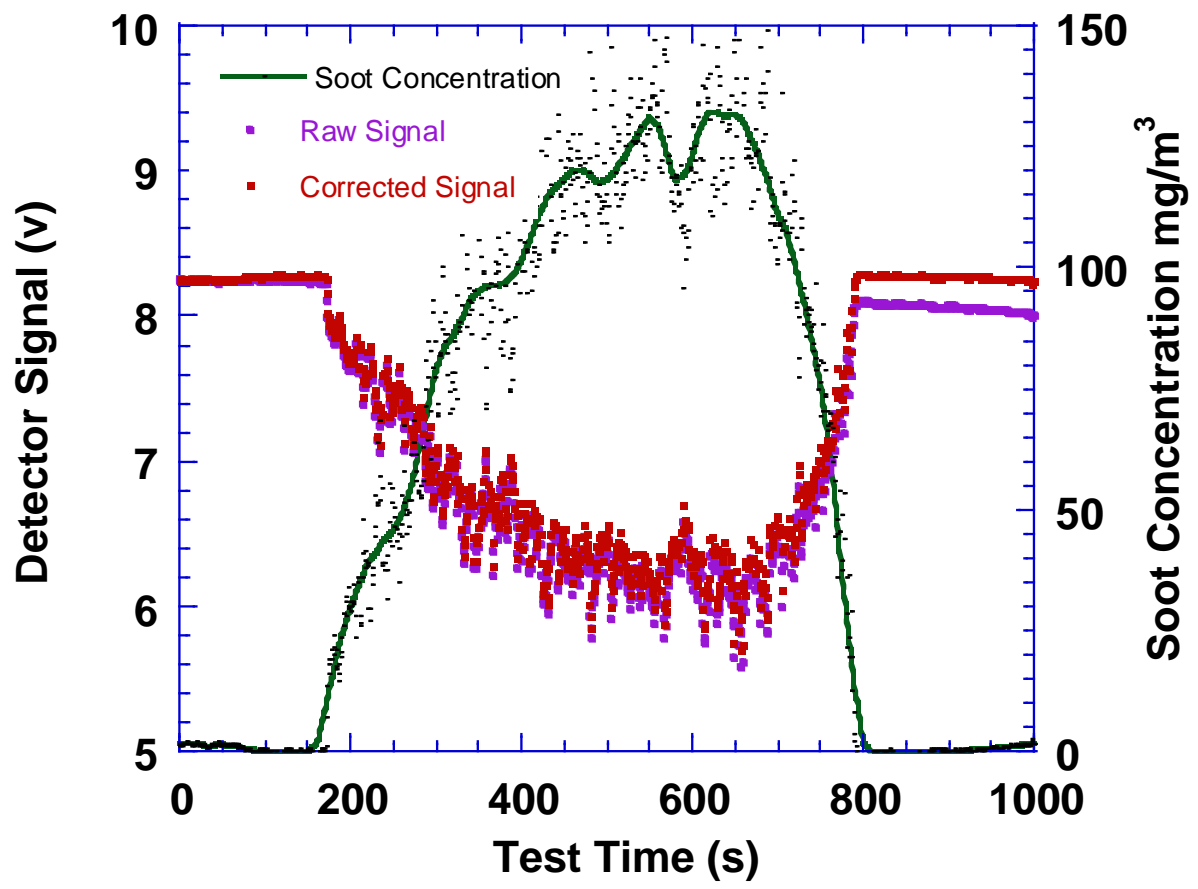

Figure 10. Soot concentration determined from the baseline corrected laser signal measured in the fire exhaust duct exit after the wet scrubber during Test 9. 


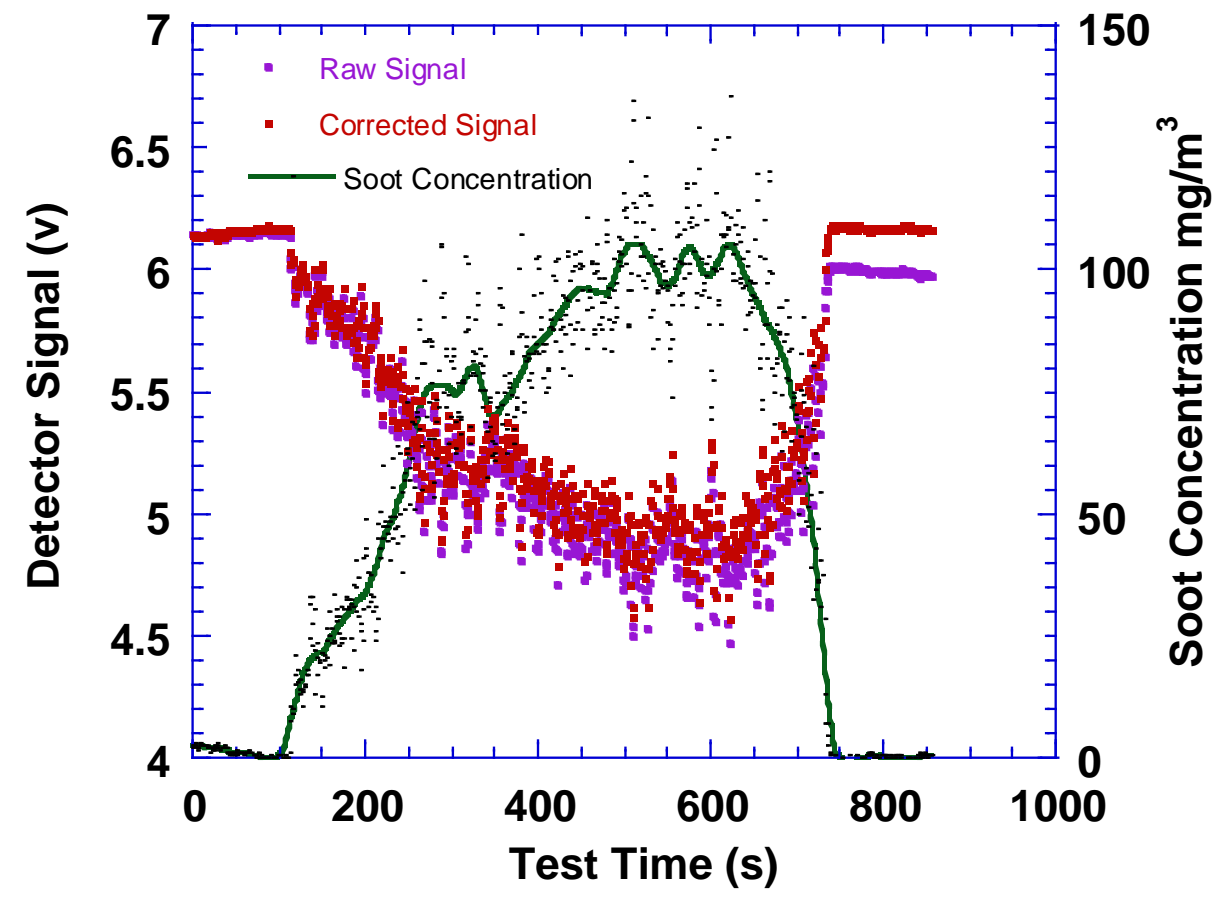

Figure 11. Soot concentration determined from the baseline corrected laser signal measured in the fire exhaust duct exit after the scrubber (with the water not flowing) during Test 10.

was regulated with a rotometer with the flow adjusted such that it was held nearly constant throughout each experiment. The sampling time was adjusted to reduce particulate loading on the collection substrate, thus reducing sample collection biases. After each experiment, the substrates and back-up filter were weighed, then placed in a desiccator and re-weighed (more than $24 \mathrm{~h}$ ) later to obtain a stable (dry) particulate mass. The mass did not change appreciably indicating that the sample was mainly soot, not water. The relative uncertainty of the mass collected on each stage is estimated as $0.01 \mathrm{mg}$.

Figure 12 shows the cascade impactor measurement results for Test 8 (sampling after the scrubber, at the exhaust duct exit) and Test 9 (sampling before the scrubber) plotted on a log probability scale, and Table 4 summarizes the cascade impactor measurements. The amount of soot mass sampled in Test 8 was higher than in Test 9 because the sampling time was longer. The collected particulate appeared blackish as expected - typical of soot. The particle size distribution is of particular interest and there is sufficient soot mass to compare the tests. There is little if any difference in the size distribution of the two samples. The wet scrubbing system did relatively little to remove large particles from the flow. 


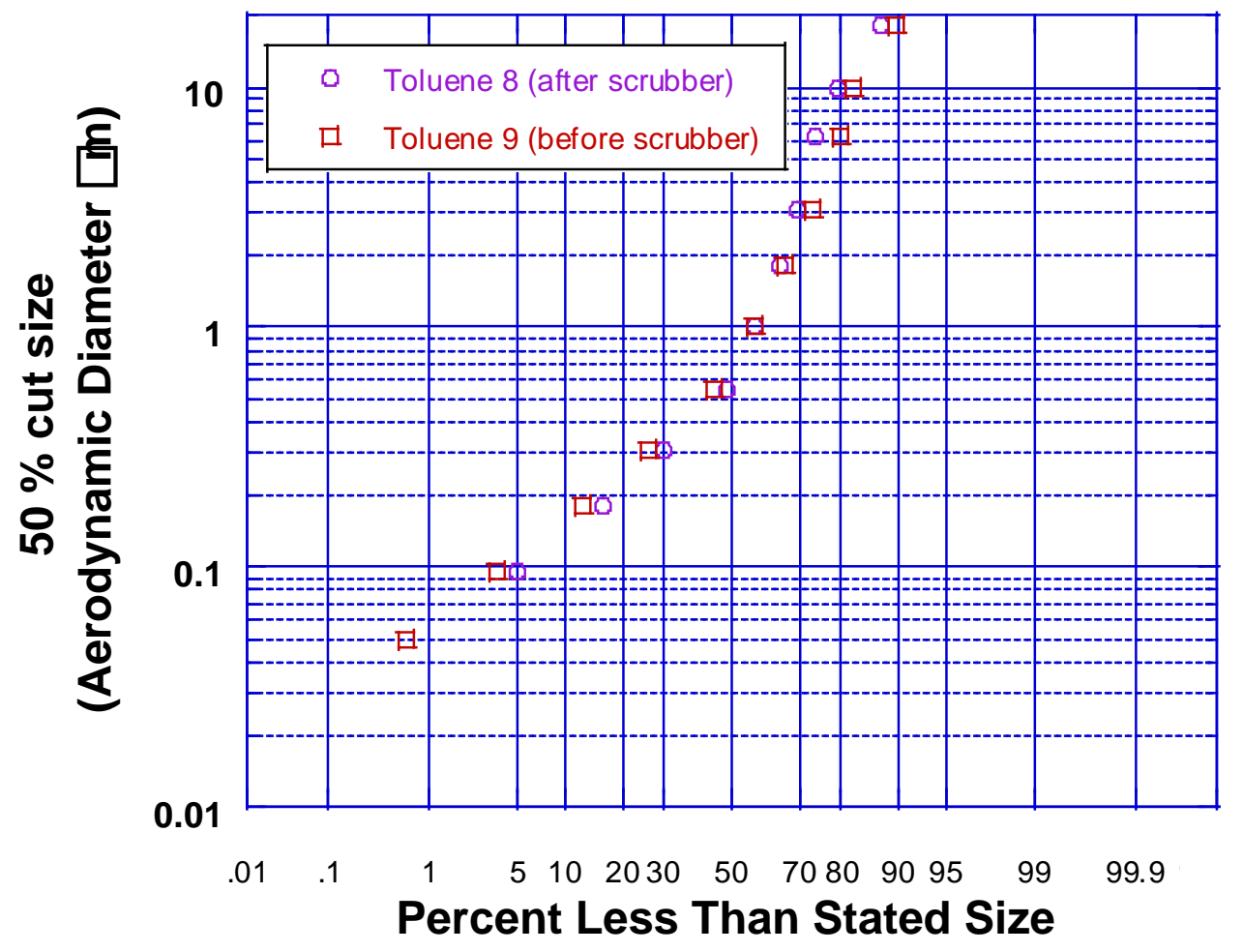

Figure 12 Measured soot aerodynamic diameter before (Test 9) and after (Test 8) the wet scrubbing system for samples extracted from the exhaust of $500 \mathrm{ml}$ toluene pool fires.

\begin{tabular}{|l|c|c|c|c|}
\hline Test \# & $\begin{array}{c}\text { Sampling } \\
\text { Location }\end{array}$ & $\begin{array}{c}\text { Mass Median } \\
\text { Diameter }(\mu \mathrm{m})\end{array}$ & $\begin{array}{c}\text { Mass percentage from soot } \\
\text { particles less than } 2.5 \mu \mathrm{m}\end{array}$ & $\begin{array}{c}\text { Mass collected } \\
(\mathrm{mg})\end{array}$ \\
\hline 8 & after scrubber & 0.65 & $69 \%$ & 8.9 \\
\hline 9 & before scrubber & 0.75 & $69 \%$ & 5.1 \\
\hline
\end{tabular}

Table 4. Summary of the cascade impactor measurements.

\section{Conclusions}

Two series of fire experiments were conducted in NIST's National Fire Research Laboratory to test technologies for possible use in the filtration of soot from the exhaust stream of $20 \mathrm{~cm}$ diameter pool fires burning $500 \mathrm{ml}$ of toluene. The first experimental series used two large surface area pleated cartridge filters to capture particulate in the gas phase. The second series of experiments employed a wet scrubbing system. The experiments showed that neither technology provided adequate soot filtration. The gas phase filtering system rapidly clogged. The performance of the wet scrubbing system was found to be inadequate. The wet scrubbing system could possibly collect a significant portion of the exhaust particulate by significantly extending its length or putting several scrubbers in series; but its length would need to be prohibitively large, which is impractical in terms of available space. The use of other technologies to efficiently scrub soot ought to be investigated. 


\section{Acknowledgements}

The authors are grateful to Lauren DeLauter, Doris Rinehart and Mike Selepak for their expert help conducting the experiments and to Andrew Lock of CPSC and Josh Dinaburg of JensenHughes Associates for helpful discussions and assistance.

\section{References}

1. Hurley, M., (Ed.), SFPE Handbook, Fifth Edition, Appendix 3, Society of Fire Protection Engineers, 3437 (2015).

2. Personal Communication, Stanislav Stoliarov, the University of Maryland at College Park, February 2016.

3. Personal Communication, Joshua Dinaburg, Hughes Associates, November 2015.

4. Personal Communication, Andrew Lock, Consumer Products Safety Commission, January 2016.

5. Personal Communication, Nicholas Dembsey, Worcester Polytechnic Institute, April 2015.

6. Jensen Hughes, Consumer Product Safety Commission Smoke Abatement Upgrade: Phase IDesign Study and Construction Estimate, Project 1JBD00002.000, prepared for the Consumer Product Safety Commission, May 15, 2015.7. Mulholland, G., and Coarkin, C., Specific Extinction Coefficient of Flame Generated Smoke, Fire and Materials, 24, 227-230 (2000). 